Voix et Images

voixetimages

\title{
Prix Jeune chercheur Voix et Images
}

\section{Robert Dion}

Volume 39, numéro 2 (116), hiver 2014

URI : https://id.erudit.org/iderudit/1025184ar

DOI : https://doi.org/10.7202/1025184ar

Aller au sommaire du numéro

Éditeur(s)

Université du Québec à Montréal

ISSN

0318-9201 (imprimé)

1705-933X (numérique)

Découvrir la revue

Citer ce document

Dion, R. (2014). Prix Jeune chercheur Voix et Images. Voix et Images, 39(2), 5-5. https://doi.org/10.7202/1025184ar d'utilisation que vous pouvez consulter en ligne.

https://apropos.erudit.org/fr/usagers/politique-dutilisation/ 


\author{
AVA N T-PROPOS \\ Prix Jeune chercheur Voix et Images \\ $+++$ \\ ROBERT DION \\ Université du Québec à Montréal
}

Consciente de la nécessité de préparer une relève bien formée et dynamique, la revue Voix et Images a lancé, il y a quelques années, son prix Jeune chercheur. Attribué tous les deux ans, ce prix distingue un travail de recherche particulièrement abouti, publiê dans la revue par un(e) étudiant(e) ou un(e) stagiaire postdoctoral(e), abordant des questions littéraires ou culturelles concernant le Québec ou le Canada français. Cette année, la lauréate du prix est Marie-Hélène Constant, auteure de l'article intitulé «De la judéité souterraine au texte-crypte dans Barney's Version de Mordecai Richler » et publié dans le numéro 114 de la revue (printemps-été 2013).

Composé de Lori Saint-Martin, de Jacques Dubois et de Jacques Pelletier, le jury a souligné «l'importance du sujet retenu, soit le rapport dialectique, et parfois polémique, qu'entretenait Richler à la judéité, et la finesse de la lecture proposée». Il a au surplus noté que, « [t] out en puisant dans une abondante documentation, l'article offre une interprétation originale et éclairante».

En mon nom et au nom du comité de rédaction, j'adresse toutes mes félicitations à la lauréate. 